\title{
Preparation of Biphenyl-Conjugated Bromotyrosine for Inhibition of PD-1/PD-L1 Immune Checkpoint Interactions
}

\author{
Eun-Hye Kim ${ }^{1,2}$, Masuki Kawamoto ${ }^{1,3, *}$, Roopa Dharmatti ${ }^{1}$, Eiry Kobatake ${ }^{2}$, Yoshihiro Ito ${ }^{1,3}$ \\ and Hideyuki Miyatake ${ }^{1, *}$ \\ 1 Nano Medical Engineering Laboratory, RIKEN Cluster of Pioneering Research, 2-1 Hirosawa, Wako, \\ Saitama 351-0198, Japan; eunhye.kim@riken.jp (E.-H.K.); roopa.dharmatti@riken.jp (R.D.); \\ y-ito@riken.jp (Y.I.) \\ 2 Department of Life Science and Technology, School of Life Science and Technology, \\ Tokyo Institute of Technology, 4259 Nagatsuta-cho, Midori-ku, Yokohama 226-8503, Japan; \\ kobatake.e.aa@m.titech.ac.jp \\ 3 Emergent Bioengineering Materials Research Team, RIKEN Center for Emergent Matter Science, \\ 2-1 Hirosawa, Wako, Saitama 351-0198, Japan \\ * Correspondence: mkawamot@riken.jp (M.K.); miyatake@riken.jp (H.M.); Tel.: +81-48-467-2752 (M.K.); \\ +81-48-467-4979 (H.M.); Fax: +81-48-467-9300 (M.K.); +81-48-467-9300 (H.M.)
}

Received: 7 April 2020; Accepted: 17 May 2020; Published: 21 May 2020

\begin{abstract}
Cancer immunotherapy has been revolutionized by the development of monoclonal antibodies (mAbs) that inhibit interactions between immune checkpoint molecules, such as programmed cell-death 1 (PD-1), and its ligand PD-L1. However, mAb-based drugs have some drawbacks, including poor tumor penetration and high production costs, which could potentially be overcome by small molecule drugs. BMS-8, one of the potent small molecule drugs, induces homodimerization of PD-L1, thereby inhibiting its binding to PD-1. Our assay system revealed that BMS-8 inhibited the PD-1/PD-L1 interaction with $\mathrm{IC}_{50}$ of $7.2 \mu \mathrm{M}$. To improve the $\mathrm{IC}_{50}$ value, we designed and synthesized a small molecule based on the molecular structure of BMS- 8 by in silico simulation. As a result, we successfully prepared a biphenyl-conjugated bromotyrosine (X) with $\mathrm{IC}_{50}$ of $1.5 \mu \mathrm{M}$, which was about five times improved from BMS-8. We further prepared amino acid conjugates of $\mathbf{X}$ ( $\mathbf{a m i n o}-\mathbf{X})$, to elucidate a correlation between the docking modes of the amino-Xs and $\mathrm{IC}_{50}$ values. The results suggested that the displacement of amino-Xs from the BMS-8 in the pocket of PD-L1 homodimer correlated with $\mathrm{IC}_{50}$ values. This observation provides us a further insight how to derivatize $\mathbf{X}$ for better inhibitory effect.
\end{abstract}

Keywords: PD-1/PD-L1; immune checkpoint inhibitors; biphenyl-conjugated bromotyrosine; amino acid conjugation; amino-X; in silico simulation; $\mathrm{IC}_{50}$

\section{Introduction}

Immunotherapy has recently emerged as a fourth modality for cancer therapy, together with surgery, chemotherapy, and radiation therapy [1-4]. The immunotherapy promotes T-cells to kill cancer cells by the blockade of immune checkpoint pathways [5,6]. One of the major immune checkpoint pathways is inactivated by the binding of programmed cell-death 1 (PD-1) [7], which is largely expressed on T cells, and its ligand PD-L1 [3,8,9], which is mainly expressed on antigen-presenting cells under physiological conditions but is upregulated on cancer cells [10]. PD-L1 binding to PD-1 suppresses T-cell function, including cytolytic activity, leading to downregulation of the anti-tumor immune response [2,5]. Another immune checkpoint is mediated by binding of the ligands B7-1/2 
(CD80, CD86) on activated antigen-presenting cells or cancer cells to cytotoxic T-lymphocyte-associated protein 4 (CTLA-4) on T cells, which also suppresses T-cell activity [11,12]. Identification of these immunosuppressive pathways led to the development of monoclonal antibody ( $\mathrm{mAb}$ )-based cancer therapies that inhibit PD-1/PD-L1 or CTLA-4/B7 pathways, thereby reinvigorating the host anti-tumor immune response [2,13-17]. Among the therapies currently approved for clinical use are the anti-CTLA-4 mAb ipilimumab (Yervoy ${ }^{\mathbb{R}}$ ), which was the first immune checkpoint inhibitor to demonstrate an anti-cancer effect $[18,19]$, and the anti-PD-1 mAb nivolumab (Opdivo ${ }^{\circledR}$ ) [20]. In addition to these and other approved mAb-based immune checkpoint inhibitors [21], many others are currently in clinical trials for various cancers and immune-based diseases [22-25].

Protein-based drugs such as mAbs have some important drawbacks, such as high production costs associated with the preparation of biologicals [26], poor tumor penetration due to their large molecular weights ( 150 kDa) [27], and unexpected post-translational glycosylation patterns [28]. Small molecule drugs, which are generally orally active and can overcome many of the challenges associated with protein drugs, are therefore being pursued as attractive alternative immune checkpoint inhibitors [28,29].

Until now, Bristol-Myers Squibb (BMS) has disclosed the patent claim [30] with structures of a number of BMS compounds, which are the potential inhibitors of the PD-1/PD-L1 pathway. Previous works have shown that one of the BMS compounds, BMS-8, binds directly to PD-L1 and induces formation of PD-L1 homodimers, which in turn prevents the interaction with PD-1 [31]. In the patent claims, the homogenous time-resolved fluorescence (HTRF) assay report that BMS-8 has a sub $\mu \mathrm{M}$ order of $\mathrm{IC}_{50}, 0.146 \mu \mathrm{M}$ [30], with other BMS compounds [32]. In this study, however, our amplified luminescence proximity homogeneous assay (Alpha) measured the $\mathrm{IC}_{50}$ of $\mathbf{B M S}-8$ as $7.2 \mu \mathrm{M}$. Therefore, we aimed to prepare higher affinity compounds by taking the advantage of the complex structure of BMS-8/PD-L1 [31] with in silico simulation [33-35]. Figure 1 shows our strategies to improve the affinity of BMS-8. We used fragmented structures of 3-hydroxymethyl-2-methylbiphenyl (1) and 3-bromotyrosine (2). After conjugation of $\mathbf{1}$ and 2, a biphenyl-conjugated bromotyrosine (denoted as $\mathbf{X}$ ) was synthesized. Because an amino and carboxyl group included in $\mathbf{X}$, it could be conjugated to various amino acids. [36,37]. During the procedures, we employed in silico simulation and $\mathrm{IC}_{50}$ assay to reveal molecular mechanism of the inhibition.

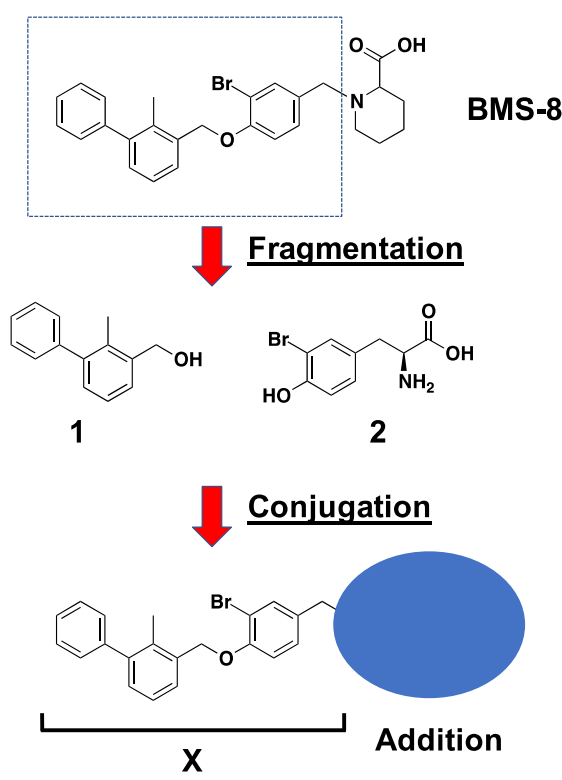

Figure 1. Strategies to improve inhibitory effect of BMS-8. 3-hydroxymethyl-2-methylbiphenyl (1) and 3-bromotyrosine (2) were selected as fragmented structures. A biphenyl-conjugated bromotyrosine $\mathbf{X}$ was synthesized after conjugation of $\mathbf{1}$ and $\mathbf{2}$. We conjugated a variety of amino acids as additions, to the amino- and carboxyl-groups of $\mathbf{X}$ to reveal molecular mechanism of the inhibition. 


\section{Results}

\subsection{In Silico Docking Simulation and Organic Chemistry Synthesis of a Biphenyl-Conjugated Bromotyrosine}

We designed a biphenyl-conjugated bromotyrosine (denoted as $\mathbf{X}$ ), based on the BMS-8. We docked $\mathbf{X}$ into the crystal structure of $\mathbf{B M S - 8 / P D - L 1} 1_{\mathrm{AB}}$ complex (PDB ID: 5J8O) [31] using ICM 3.8-7 software (Molsoft L.L.C., San Diego, CA, USA) [33-35], without guidance and induced fitting to avoid over-fitting. We obtained the docking score of -42.96 for $\mathbf{X}$, which was the same order of BMS-8, -49.5 (Table 1). Based on the scores, we confirmed the potential of $\mathbf{X}$ for inhibition. Therefore, we synthesized $\mathbf{X}$ by the organic chemistry procedures. Scheme 1 shows the synthetic route for a biphenyl-bromotyrosine 6. Full synthesis details are provided in Materials and Methods. The C- and N-terminals of 3-bromotyrosine (2) were first protected by tert-butyl and fluorenylmethyloxycarbonyl (Fmoc) groups, respectively, to produce the amino acid 4, which was then reacted with 3-hydroxymethyl-2-methylbiphenyl (1) through the Mitsunobu reaction to yield compound 5. Deprotection of the tert-butyl group in compound 5 produced the Fmoc-protected amino acid $\mathbf{6}$. Deprotection of the Fmoc group in $\mathbf{6}$ yielded the compound $\mathbf{X}$. Peptide conjugates were obtained by solid-state peptide synthesis using compound 6. ${ }^{1} \mathrm{H}$ NMR spectra of the compounds are shown in Figures S1-S4. A summary of the analytical data for the synthesized compounds is given in Table S1. The analytical data indicate the successful synthesis of $\mathbf{X}$ and 29 amino-X derivatives consisting of 2-mers (GX, XG, XS, XR, XA, XW), 3-mers (YXC, WXG, QXQ, CXA, RXN, SXR, NXR, CXR, GXG, XNL, XNH, XHP, XGG), 4-mers (XCSE, XGGG), 5-mers (WRXNN, ERXNK, WRXNQ, XRRRR, XGGGG), 6-mer (XGGGGG), and 7-mers (CERXNKM, FWRXNNI).

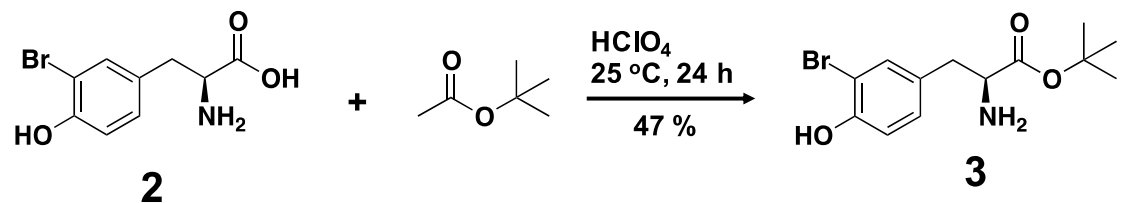<smiles>CC(C)(C)OC(=O)[C@H](Cc1ccc(O)c(Br)c1)NC(=O)OCC1c2ccccc2-c2ccccc21</smiles>

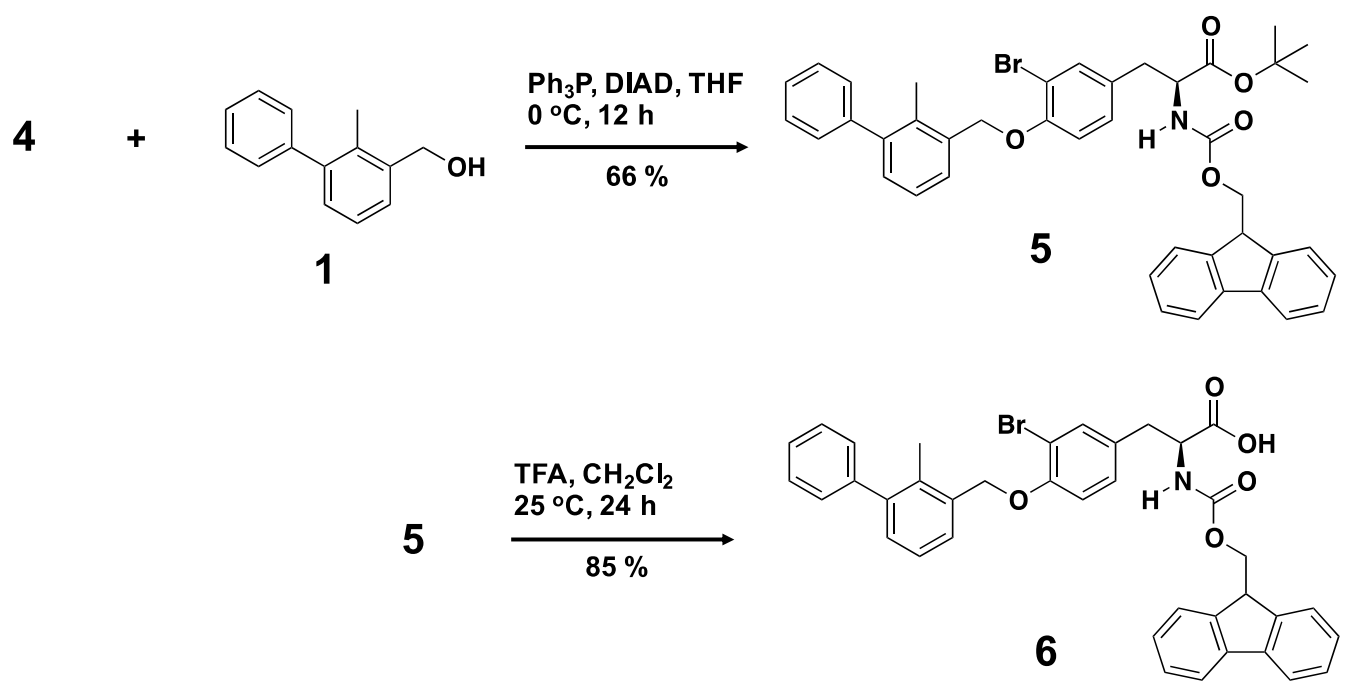

Scheme 1. Synthetic scheme for the biphenyl-conjugated bromotyrosine 6 . 
Table 1. Docking simulation and $\mathrm{IC}_{50}$ measurements of BMS-8 and amino-Xs.

\begin{tabular}{|c|c|c|c|c|}
\hline Amino Acid Length & Sequence & Score & RMSD (Å) & $\mathrm{IC}_{50}(\mu \mathrm{M})$ \\
\hline- & BMS-8 & -49.5 & - & 7.2 \\
\hline 1 & $x$ & -42.96 & 0.40 & 1.5 \\
\hline \multirow{6}{*}{2} & GX & -41.0 & 0.52 & 448.5 \\
\hline & XG & -46.9 & 0.28 & 2.1 \\
\hline & XS & -42.1 & 0.60 & 2655.0 \\
\hline & $\mathrm{XR}$ & -45.7 & 0.37 & 892.0 \\
\hline & XA & -43.1 & 0.47 & 22.3 \\
\hline & XW & -43.3 & 0.51 & 845.0 \\
\hline \multirow{13}{*}{3} & YXC & -37.1 & 0.46 & 465.0 \\
\hline & WXG & -50.6 & 0.48 & 404.8 \\
\hline & QXQ & -37.7 & 0.73 & 1961.0 \\
\hline & CXA & -42.0 & 0.48 & 665.0 \\
\hline & RXN & -40.3 & 0.63 & 405.3 \\
\hline & SXR & -36.7 & 0.58 & 796.0 \\
\hline & NXR & -50.3 & 0.46 & 982.0 \\
\hline & CXR & -41.5 & 0.54 & 550.0 \\
\hline & GXG & -43.6 & 0.39 & 676.0 \\
\hline & XNL & -43.0 & 0.58 & 855.0 \\
\hline & XNH & -40.7 & 0.50 & 313.0 \\
\hline & XHP & -33.5 & 0.55 & 359.0 \\
\hline & XGG & -36.1 & 0.57 & 6505.0 \\
\hline \multirow{2}{*}{4} & XCSE & -32.6 & 0.45 & 1555.0 \\
\hline & XGGG & -53.3 & 0.51 & 6766.0 \\
\hline \multirow{5}{*}{5} & WRXNN & -38.1 & 0.38 & 157.4 \\
\hline & ERXNK & -21.3 & 0.48 & 15.6 \\
\hline & WRXNQ & -19.4 & 0.49 & 163.2 \\
\hline & XRRRR & -28.3 & 0.45 & 435.6 \\
\hline & XGGGG & -41.8 & 0.75 & 647.5 \\
\hline 6 & XGGGGG & -45.3 & 0.48 & 846.0 \\
\hline \multirow{2}{*}{7} & CERXNKM & 4.65 & 1.80 & 308.2 \\
\hline & FWRXNNI & -7.30 & 0.41 & 311.8 \\
\hline
\end{tabular}

\subsection{Inhibition Assays of PD-1/PD-L1 Binding by BMS-8 and X}

To evaluate the binding affinities of the compounds for PD-L1, we used the amplified luminescence proximity homogeneous assay (Alpha) by using the AlphaLISA ${ }^{\circledR}$ assay kit [38]. This assay is based on photoinduced energy transfer between donor and acceptor beads conjugated to PD-1 and PD-L1, respectively (Figure S6).

The AlphaLISA ${ }^{\circledR}$ assay revealed that the intermediates of $\mathbf{X}$, compounds $\mathbf{1 - 6}$, showed a few hundred $\mu \mathrm{M}$ or weaker $\mathrm{IC}_{50}$ values (Figure 3). BMS-8 inhibited the PD-1/PD-L1 interaction with $\mathrm{IC}_{50}$ of $7.2 \mu \mathrm{M}$ (Figure 2), which was weaker than that previously reported, $\mathrm{IC}_{50}$ of $0.146 \mu \mathrm{M}$ [30]. On the other hand, nivolumab showed nano-molar order of inhibition ( $\mathrm{IC}_{50}=5.1 \mathrm{nM}$, Figure 2$)$, corresponding to the previously reported value [39], which suggests the validity of our assay system. 

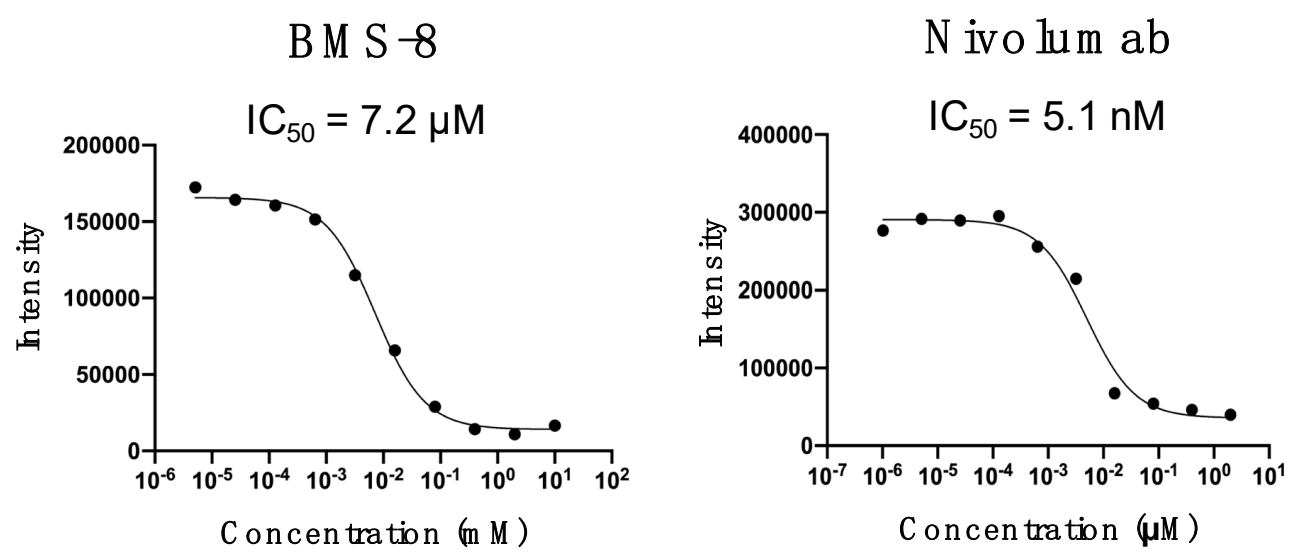

Figure 2. Inhibition of PD-1/PD-L1 interaction by BMS-8 and nivolumab measured by the AlphaLISA ${ }^{\circledR}$ assay.

\subsection{Fragmentation of BMS-8 and Conjugation of Compounds to Prepare $X$}

To prepare higher affinity compounds based on BMS-8, we first considered a scenario that smaller groups of BMS-8, compounds 1-6 (Scheme 1), showed better inhibitory effect for PD-1/PD-L1 PPI. The docking scores of the compounds, however, were larger than that of BMS-8 (-49.5), suggesting pooper inhibition effect. Actually, AlphaLISA assay revealed that the $\mathrm{IC}_{50}$ values were a few hundred $\mu \mathrm{M}$, which were much weaker than that of BMS-8 (7.2 $\mu \mathrm{M})$ (Figure 3).

\begin{tabular}{|l|l|l|}
\hline Compound & Score & $\mathbf{C}_{50}(\mathbf{M})$ \\
\hline Compound1 & -35.82 & 309.1 \\
\hline Compound2 & -10.05 & $\mathrm{~N} / \mathrm{V}$ \\
\hline Compound3 & -0.1608 & $\mathrm{~N} / \mathrm{V}$ \\
\hline Compound4 & -11.77 & 1061 \\
\hline Compound5 & -29.9 & 896.9 \\
\hline Compound6 & -40.31 & 1418 \\
\hline
\end{tabular}
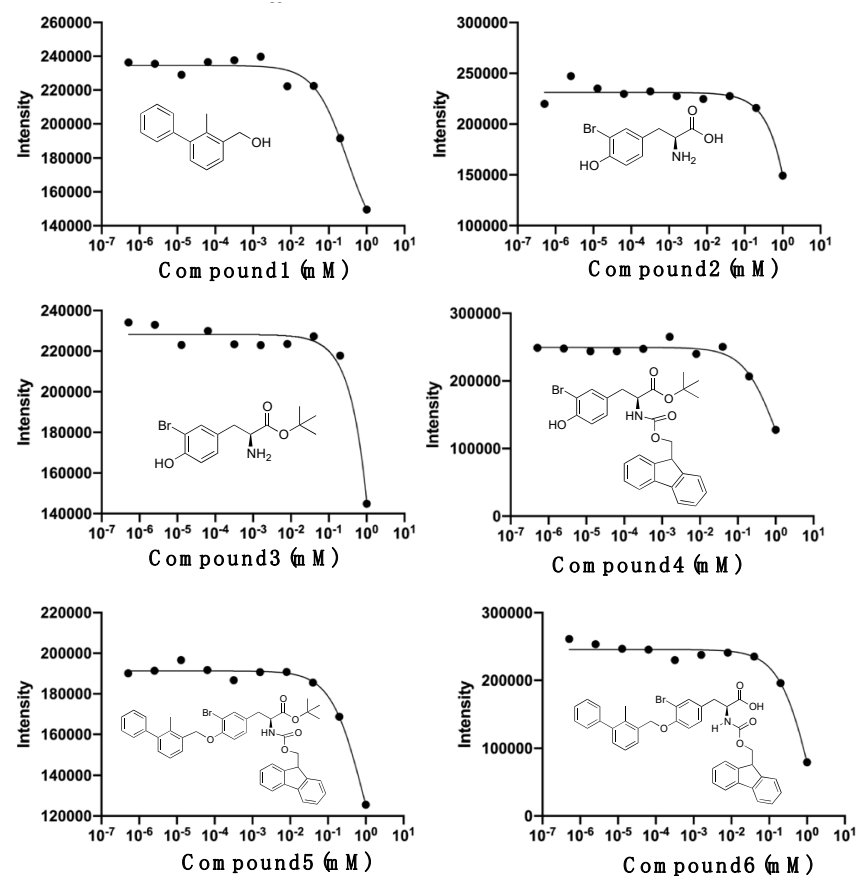

Figure 3. Docking scores, $\mathrm{IC}_{50}$ values and measurements of compounds 1-6. All compounds showed larger scores than that of $\mathbf{X}($ score $=-42.96)$ with a few hundred $\mu \mathrm{M}$ of $\mathrm{IC}_{50}$ values.

Therefore, we considered the next scenario of conjugation of compounds; we conjugated compound $\mathbf{4}$ and compound 1 to prepare biphenyl-bromotyrosine ( $\mathbf{X})$, which resembled BMS-8 except the terminal amino- and carboxyl-groups. In turn, $X$ showed a docking score of -42.96 , comparable to that of BMS-8 (-49.5). In fact, $\mathbf{X}$ inhibited PD-1/PD-L1 PPI with $\mathrm{IC}_{50}=1.5 \mu \mathrm{M}$ (Figure 4), which was five times better than that of BMS-8 $(7.2 \mu \mathrm{M})$. 


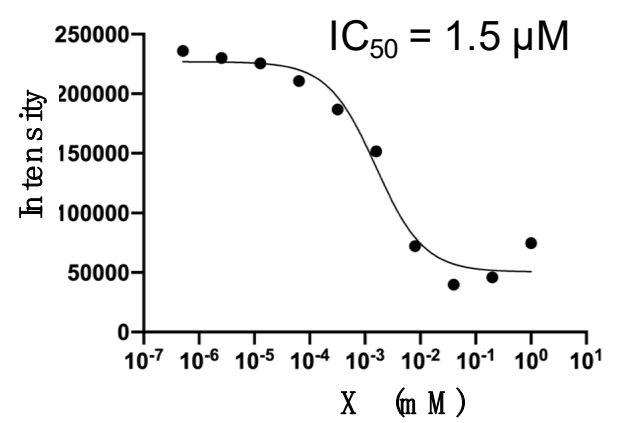

Figure 4. AlphaLISA assay of $\mathbf{X} . \mathbf{X}$ shows $\mathrm{IC}_{50}=1.5 \mu \mathrm{M}$ with docking score $=-42.96$.

\subsection{Docking Simulation and Inhibition Assay of Amino-Xs}

The binding mode of the BMS compounds and derivatives to PD-L1 has previously been revealed by X-ray crystallography [31,40-42]. BMS compounds induces transient homodimerization of PD-L1 $1_{\mathrm{AB}}$ on the binding, which masks the binding site for PD-1 located in the homodimerization interface. We docked amino-Xs to the crystal structure of BMS-8/PD-L1 ${ }_{\mathrm{AB}}$ complex (PDB ID: 5J8O) [31], using ICM 3.8-7 software (Molsoft L.L.C., San Diego, CA, USA) [33-35], without guidance and induced fitting to avoid over-fitting. After the docking, we calculated the root mean square deviation (RMSD) of distances between atoms in compound BMS-8 and $\mathbf{X}$, excluding $\mathrm{C} \alpha, \mathrm{NH}_{2}$, and $\mathrm{COOH}$ atoms (Figure 5).

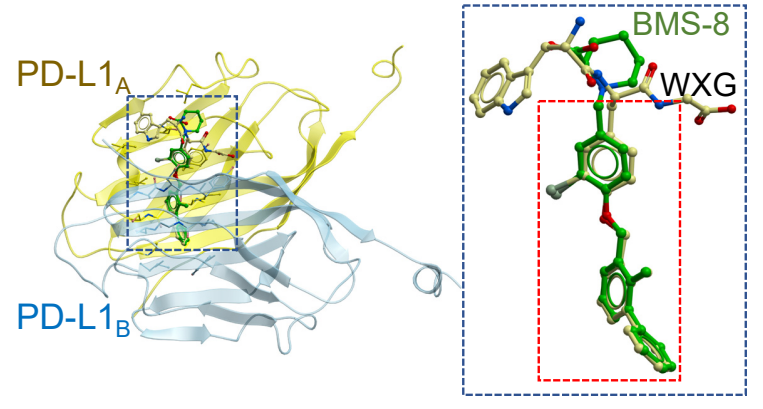

Figure 5. Root mean square deviation (RMSD) calculation between amino- $X$ and BMS-8 bound to PD-L1 $1_{\mathrm{AB}}$ homodimer. After docking of amino-X (in this case, WXG), we calculated RMSD between a part of WXG (excluding C $\alpha$, amino-group and carboxyl-group) and the corresponding part of BMS-8, as shown by the red dotted-rectangle.

Table 1 shows the docking scores and RMSD values for amino-Xs docked to PD-L1 $1_{\mathrm{AB}}$. Also, the $\mathrm{IC}_{50}$ values for the amino-Xs are listed in Table 1. As a result, they suggested some positive correlations. The $\mathrm{IC}_{50}$ values of the 1-2-mer amino-Xs showed moderate correlations with both the RMSDs (CC 0.67, Table 2) and the scores (CC 0.40, Table 2). However, these correlations weakened as the number of conjugated amino acids increased (RMSD from 0.67 to 0 and CC 0.40 to -0.20 , Table 2). These results suggest that the current in silico docking worked better for amino-Xs conjugated with shorter amino acids.

Table 2. Correlation coefficients $(\mathrm{CC})$ for $\mathrm{IC}_{50}$ vs. Score and $\mathrm{IC}_{50}$ vs. RMSD.

\begin{tabular}{|c|c|c|}
\hline Length & $\mathrm{CC}$ of Score/IC 50 & $\mathrm{CC}$ of $\mathrm{RMSD} / \mathrm{IC}_{50}$ \\
\hline $1-2$ & 0.40 & 0.67 \\
\hline $1-3$ & 0.35 & 0.37 \\
\hline $1-4$ & 0 & 0.28 \\
\hline $1-7$ & -0.20 & 0 \\
\hline
\end{tabular}

CC values were calculated by the Microsoft Excel. 
To discuss the correlations further, we compared the docking structures of $\mathbf{X}\left(\mathrm{IC}_{50}=1.5 \mu \mathrm{M}\right)$, XG $\left(\mathrm{IC}_{50}=2.1 \mu \mathrm{M}\right)$, and GX $\left(\mathrm{IC}_{50}=448.5 \mu \mathrm{M}\right)$.

We compared the binding modes of BMS-8 and $\mathbf{X}$ in the pocket of PD-L1 $1_{\mathrm{AB}}$ homodimer (Figure 6). BMS-8, with $\mathrm{IC}_{50}$ of $7.2 \mu \mathrm{M}$ (Figure 2), binds the pocket with a hydrogen bind to $\mathrm{Q} 6_{\mathrm{A}}$ and a hydrophobic interaction with $\mathrm{V} 68_{\mathrm{A}}$ (Figure $6 \mathrm{~A}$ ), respectively. On the other hand, $\mathbf{X}$ forms a hydrogen bond with the hydroxy group of the side chain of $\mathrm{Y}_{56} \mathrm{~A}$, which stabilizes the binding (Figure 6A), with $\mathrm{IC}_{50}$ of $1.5 \mu \mathrm{M}$ (Figure 4). The superposition of $\mathbf{X}$ onto BMS-8 showed an RMSD displacement of $0.40 \AA$ (Figure 6B) We conclude that binding of $\mathbf{X}$ would not markedly impede PD-L1 homodimerization, which is consistent with its relatively low $\mathrm{IC}_{50}$ value of $1.5 \mu \mathrm{M}$ (Figure 4). These results suggest that we can improve an $\mathrm{IC}_{50}$ value by substituting the six-membered group of BMS-8 with some proper groups, leading to rearrangement of interactions around it. Besides, smaller displacement of biphenyl-bromotyrosine portion shown by RMSD is preferable for higher affinity.
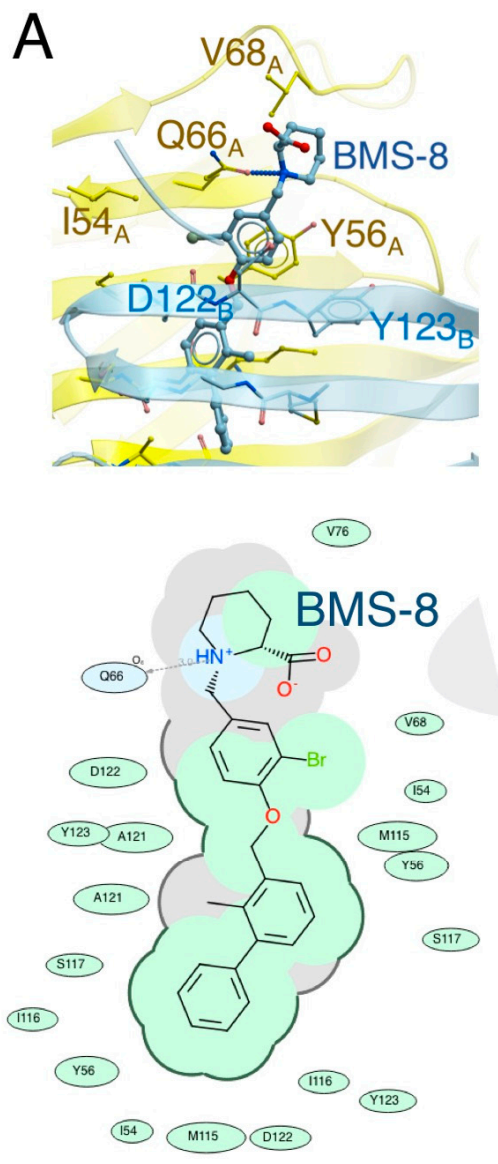

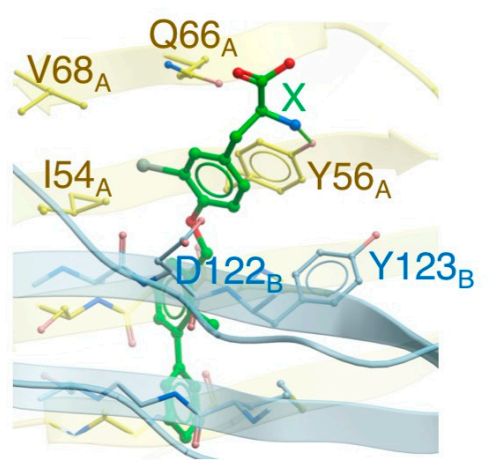

(176)

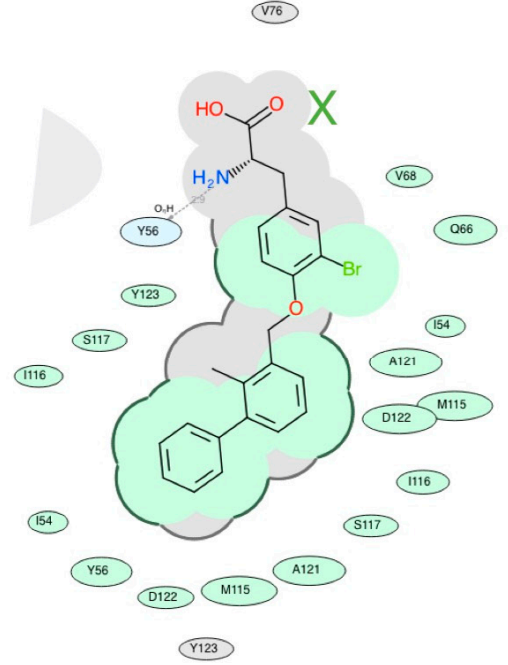

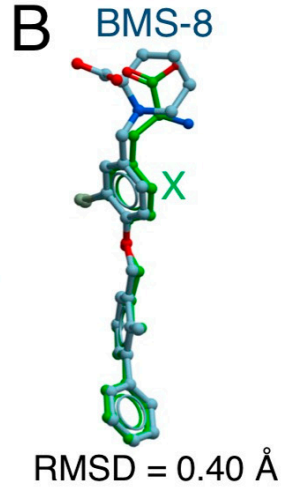

$\mathrm{RMSD}=0.40 \AA$

Figure 6. Docking conformations of BMS-8 and X. (A) The docking modes of BMS-8 and X were revealed by the $\mathrm{X}$-ray crystallography and in silico docking simulation, respectively, which the $2 \mathrm{D}$ binding pictures. The 2D figures show that biphenyl portions of the ligands bind into the pocket by hydrophobic interactions shown in light-green color. In contrast, the amino cation at the six-membered ring of BMS-8 makes a hydrogen bond with the sidechain of $\mathrm{Q}^{2} 6_{\mathrm{A}}$ in cyan color. In addition, the six-membered ring makes hydrophobic interaction with $\mathrm{V} 68_{\mathrm{A}}$. On the other hand, amino-group of bromo-tyrosine in $\mathrm{X}$ makes a hydrogen bonding to the hydroxyl group of $\mathrm{Y} 56_{\mathrm{A}}$ colored in cyan, without other hydrophobic interaction, as shown in the 2D picture. (B) BMS-8 and $\mathbf{X}$ without $\mathrm{C} \alpha, \mathrm{NH}_{2}$, and $\mathrm{COOH}$ superposed each other with RMSD of $0.40 \AA$.

Modeling of XG identified two potential hydrogen bonds between the N-terminal of XG and the side chain of Q66 ${ }_{A}$ and between the carboxyl group of Gly and R125 $\mathrm{B}$ in the side chain (Figure 7A). The RMSD between XG and BMS-8 was $0.28 \AA$ (Figure 7B), which suggested that the $\mathrm{IC}_{50}$ value of 
XG would be similar to that of $\mathbf{X}$. Indeed, XG had a measured $\mathrm{IC}_{50}$ for PD-1/PD-L1 binding of $2.1 \mu \mathrm{M}$ (Figure $7 C$ ). $\mathbf{X}$ and $X G$ potentially have the inhibitory effect for PD-1/PD-L1 interaction because $K_{D}$ between PD-1 and PD-L1 are reported as $6.4 \mu \mathrm{M}$ [43].
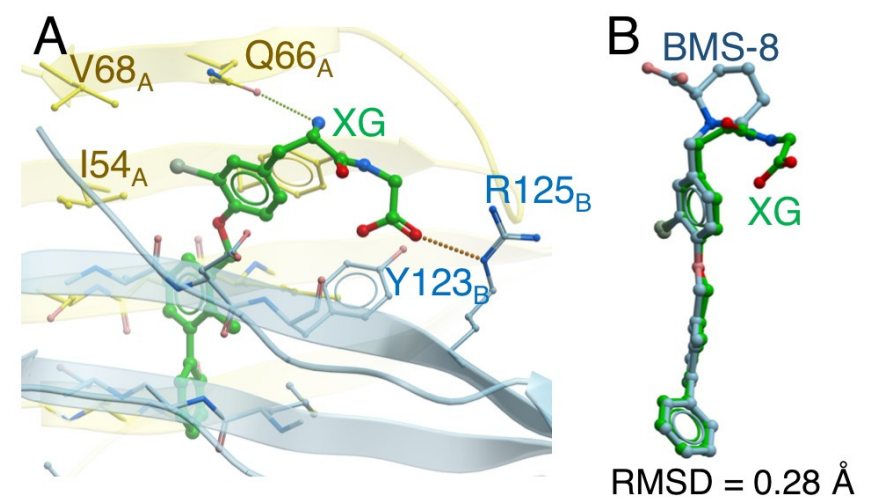

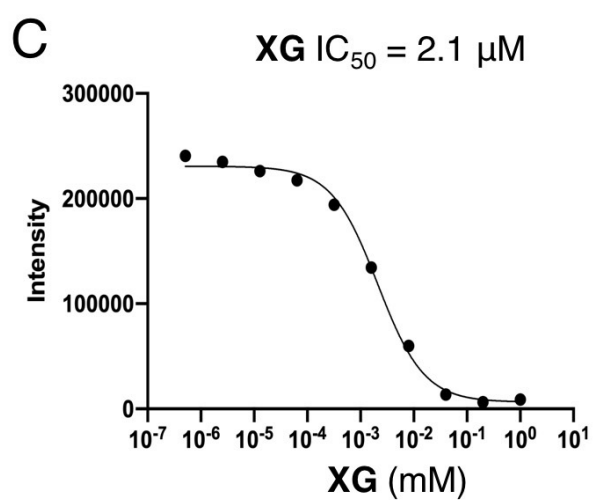

Figure 7. In silico binding mode of XG. (A) Behavior of XG in the binding pocket of the PD-L1 $1_{\mathrm{AB}}$ homodimer. (B) Superposition of XG onto BMS-8. The RMSD for displacement was $0.28 \AA$. (C) $\mathrm{IC}_{50}$ of XG for PD-1/PD-L1 binding.

GX docking into the binding pocket of the PD-L1 homodimer revealed two hydrogen bonds formed between GX amino groups and carbonyl group of $\mathrm{Y}^{123_{\mathrm{B}}}$ (Figure $8 \mathrm{~A}$ ). As a result, the calculated RMSD between GX and BMS-8 was $0.52 \AA$ (Figure 8B), which was larger than the RMSD of $\mathbf{X}$ and XG. This observation suggests that GX binding might sterically hinder PD-L1 homodimerization, leading to poorer inhibition of PD-1/PD-L1 binding. Consistent with this, the measured $\mathrm{IC}_{50}$ for GX was $448.5 \mu \mathrm{M}$ (Figure 8C), which was several hundred times higher than those for $\mathbf{X}$ and $\mathbf{X G}$ ( Figure 4; Figure 7C). It is possible that the larger displacement of $\mathbf{X}$ of $\mathbf{G X}$ caused to deform the pocket of the PD-L1 homodimer, leading to the weaker inhibition of GX than those of $\mathbf{X}$ and $\mathbf{X G}$.
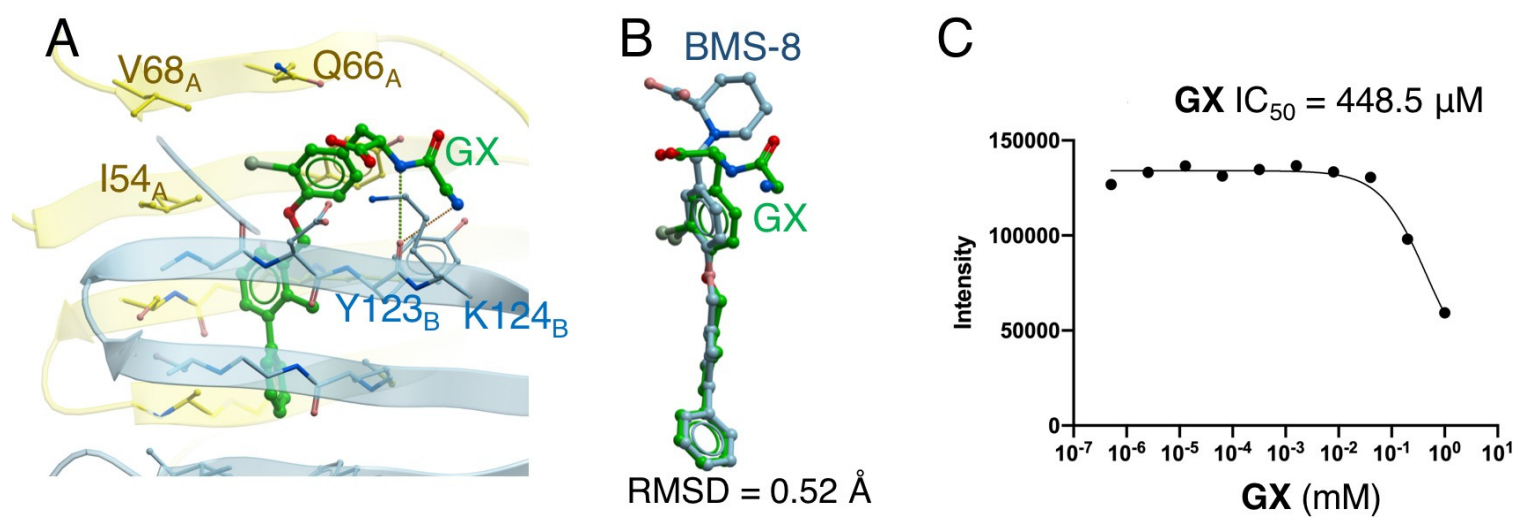

Figure 8. In silico binding mode of GX. (A) Behavior of $\mathrm{GX}$ in the binding pocket of the PD-L1 $1_{\mathrm{AB}}$ homodimer. (B) Superposition of GX onto BMS-8. The RMSD for displacement was 0.52 A RMSD. (C) $\mathrm{IC}_{50}$ of $\mathrm{GX}$ for PD-1/PD-L1 binding.

The $\mathbf{X}$ portion of $\mathbf{B M S}-8$ without $\mathrm{C} \alpha, \mathrm{NH}_{2}, \mathrm{COOH}$ atoms formed hydrophobic interactions in

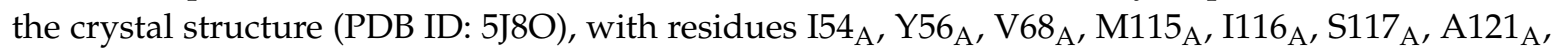
$\mathrm{D} 122_{\mathrm{A}}, \mathrm{I54_{ \textrm {B } }}, \mathrm{Y} 56_{\mathrm{B}}, \mathrm{M} 11_{\mathrm{B}}, \mathrm{I116}_{\mathrm{B}}, \mathrm{S117}_{\mathrm{B}}, \mathrm{A} 11_{\mathrm{B}}, \mathrm{D} 12_{\mathrm{B}}$, and $\mathrm{Y} 13_{\mathrm{B}}$ of the PD-L1 homodimer (Figure 9A). The space-filling representation of $\mathbf{X}$ shows the adherent interaction mode to the binding pocket (Figure 9B,C). The intermediate compounds of BMS-8, compounds 1-6 (Scheme 1) showed a poor ability to inhibit PD-1/PD-L1 binding (Figure 3), which was probably due to insufficient hydrophobic filling of the compounds in the binding pocket. 

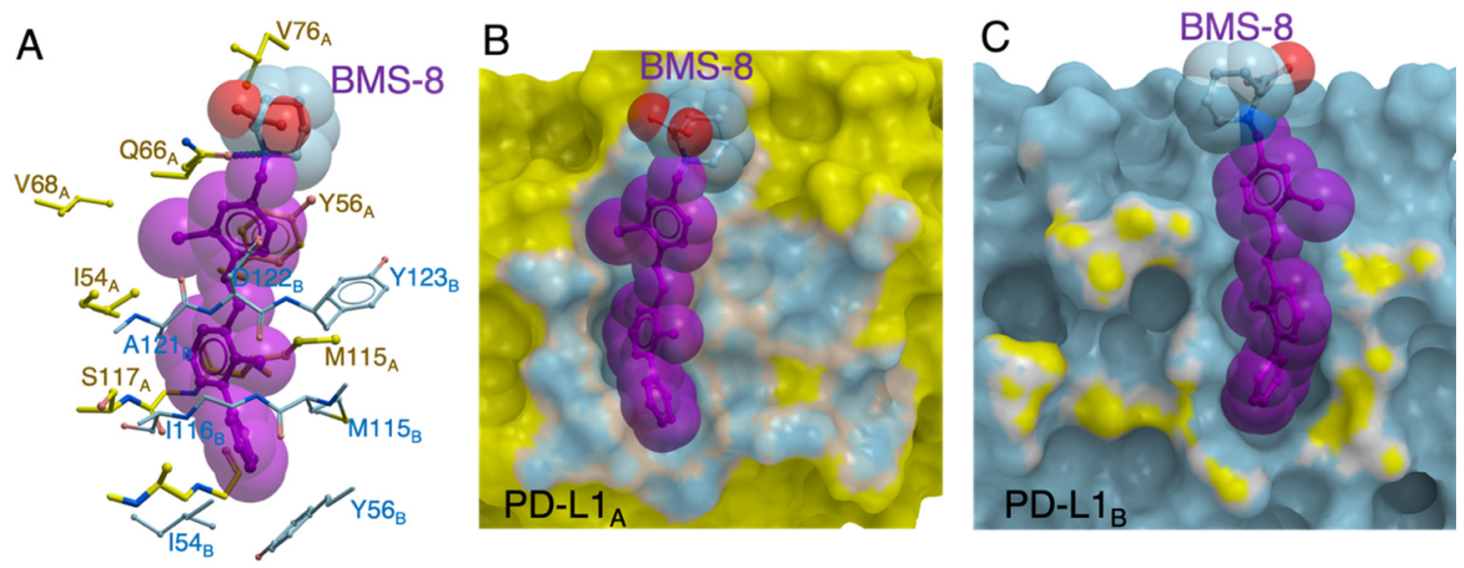

Figure 9. Schematic drawing and space-filling representation of BMS-8 binding in the binding pocket of the PD-L1 homodimer. In (A-C), violet represents $\mathbf{X}$ without $\mathrm{C} \alpha, \mathrm{NH}_{2}, \mathrm{COOH}$ atoms. (A) Binding mode of BMS-8 in the pocket of the PD-L1 ${ }_{\mathrm{AB}}$ homodimer (PDB ID:5J8O). Yellow and cyan represent PD-L1 $1_{A}$ and $P D-L 1_{B}$ side chains, respectively. (B) Space-filling representation of BMS-8 bound to the surface of PD-L1 $1_{A}$ (yellow) and contact area with PD-L1 $1_{B}$ (cyan). (C) Space-filling representation of BMS-8 bound to the surface of PD-L1 $\mathrm{B}$ (cyan) and contact area with PD-L1 $\mathrm{A}$ (yellow).

Collectively, our results suggest that the larger displacement of amino-Xs from BMS-8 prevents $\mathrm{PD}-\mathrm{L} 1_{\mathrm{A}} / \mathrm{PD}-\mathrm{L} 1_{\mathrm{B}}$ homodimer formation. The docking simulations suggest that $\mathbf{X}$ and $\mathbf{G} \mathbf{X}$ promote homodimerization of PD-L1, resulting in low $\mathrm{IC}_{50}$ values, whereas the larger displacement of amino-Xs prevents PD-L1 homodimer formation and increase the $\mathrm{IC}_{50}$ values.

The results of this study advance our understanding of how small molecule compounds could be rationally designed to inhibit PD-1/PD-L1 interactions with high affinity. In silico docking simulations have typically shown that target proteins have stable binding pockets during ligand binding, even allowing for some local flexibility of the side chains within the pockets [37,44]. In that scenario, binding scores generally correlate well with experimentally determined inhibitor activity [45]. However, binding of $\mathbf{X}$ and amino- $\mathbf{X}$ in the PD-L1 pocket occurs through strict interactions, indicating that even a slight displacement of the $\mathbf{X}$ conformation leads to deformation of the PD-L1 homodimer, which deceases the inhibitory effect. Consistent with this, the amino-Xs with shorter amino acid conjugates showed moderate positive correlations between the measured $\mathrm{IC}_{50}$ values and RMSDs in the no template/flexible docking mode, whereas the correlation was weakened by further amino acid addition.

\section{Materials and Methods}

\subsection{Materials for Organic Chemistry Synthesis}

Sodium chloride $(\mathrm{NaCl})$, lysozyme, monosodium phosphate $\left(\mathrm{NaH}_{2} \mathrm{PO}_{4}\right)$, imidazole, glycerol, reduced glutathione, oxidized glutathione, methanol, dimethyl sulfoxide (DMSO), trifluoroacetic acid (TFA), tert-butyl acetate, perchloric acid $\left(\mathrm{HClO}_{4}\right)$, hydrochloric acid $(\mathrm{HCl})$, sodium carbonate, ethyl acetate, sodium sulfate, hexane, sodium hydrogen carbonate $\left(\mathrm{NaHCO}_{3}\right)$, acetone, triphenyl phosphine $\left(\mathrm{Ph}_{3} \mathrm{P}\right)$, anhydrous dichloromethane $\left(\mathrm{CH}_{2} \mathrm{Cl}_{2}\right)$, and anhydrous tetrahydrofuran (THF) were purchased from Wako Pure Chemical Industries Ltd. (Osaka, Japan). 3-Bromo-tyrosine, 3-hydroxymethyl-2-methylbiphenyl, and diisopropyl azodicarboxylate (DIAD; 40\% in toluene, approximately $1.9 \mathrm{~mol} \mathrm{~L}^{-1}$ ) were purchased from Tokyo Chemical Industry Co., Ltd. (Tokyo, Japan). Magnesium sulfate and $\mathrm{CH}_{2} \mathrm{Cl}_{2}$ were purchased from Junsei Chemical Co., Ltd. (Tokyo, Japan). Deuterochloroform $\left(\mathrm{CDCl}_{3}\right)$ was purchased from Isotec, Inc. (Miamisburg, OH, USA), and $\mathrm{N}$-[(9H-fluoren-9-ylmethoxy) carbonyloxy] succinimide (Fmoc-Osu) was purchased from Watanabe Chemical Industries, Ltd. (Hiroshima, Japan). 
3.2. Synthesis of a Biphenyl-Conjugated Bromotyrosine<smiles>CC(=O)OC(C)(C)C</smiles>

2

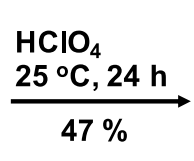

$47 \%$<smiles>CC(C)(C)OC(=O)C(N)Cc1ccc(O)c(Br)c1</smiles>

3

(S)-tert-Butyl 2-amino-3-(3-bromo-4-hydroxyphenyl) propanoate (3). A suspension of 3-bromotyrosine $(2 ; 1.0 \mathrm{~g}, 3.9 \mathrm{mmol})$ in tert-butyl acetate $(16 \mathrm{~mL}, 92 \mathrm{mmol})$ was cooled to $0{ }^{\circ} \mathrm{C}$, and stirred for $30 \mathrm{~min} . \mathrm{HClO}_{4}(0.5 \mathrm{~mL}, 7.7 \mathrm{mmol})$ was then slowly added to the suspension at $0{ }^{\circ} \mathrm{C}$, and the reaction mixture was warmed to $25^{\circ} \mathrm{C}$ and stirred for $24 \mathrm{~h}$. The mixture was washed with water and $1 \mathrm{~N} \mathrm{HCl}$, and the aqueous phase was brought to $\mathrm{pH} 9$ using sodium carbonate and then extracted with ethyl acetate. The resulting organic phase was washed with water and dried with sodium sulfate. The solvent was evaporated under reduced pressure, yielding an oily compound. This crude product was washed with cold hexane and then dried under reduced pressure to yield compound $3(0.57 \mathrm{~g}, 47 \%) .{ }^{1} \mathrm{H}-\mathrm{NMR}\left(400 \mathrm{MHz}, \mathrm{CDCl}_{3}\right): \delta=1.41\left(\mathrm{~s}, 9 \mathrm{H},-\mathrm{OC}\left(\mathrm{CH}_{3}\right)_{3}\right), 2.73(\mathrm{dd}, 1 \mathrm{H}$, $\left.\mathrm{J}=14.4,8.0 \mathrm{~Hz}, \mathrm{HOPh}(\mathrm{Br})-\mathrm{CH}_{2} \mathrm{CH}\left(\mathrm{NH}_{2}\right)-\right), 2.93\left(\mathrm{dd}, 1 \mathrm{H}, \mathrm{J}=13.6,5.2 \mathrm{~Hz}, \mathrm{HOPh}(\mathrm{Br})-\mathrm{CH}_{2} \mathrm{CH}\left(\mathrm{NH}_{2}\right)-\right)$, $3.57\left(\mathrm{dd}, 1 \mathrm{H}, \mathrm{J}=7.2,5.6 \mathrm{~Hz}, \mathrm{HOPh}(\mathrm{Br})-\mathrm{CH}_{2} \mathrm{CH}\left(\mathrm{NH}_{2}\right)-\right), 3.70\left(\mathrm{~m}, 3 \mathrm{H}, \mathrm{HOPh}(\mathrm{Br})-\mathrm{CH}_{2} \mathrm{CH}\left(\mathrm{NH}_{2}\right)-\right), 6.70$ $(\mathrm{d}, 1 \mathrm{H}, \mathrm{J}=8.0 \mathrm{~Hz}$, aromatic ring), $6.94(\mathrm{dd}, 1 \mathrm{H}, \mathrm{J}=8.4,2.0 \mathrm{~Hz}$, aromatic ring $), 7.26(\mathrm{~d}, 1 \mathrm{H}, \mathrm{J}=1.6 \mathrm{~Hz}$, aromatic ring).
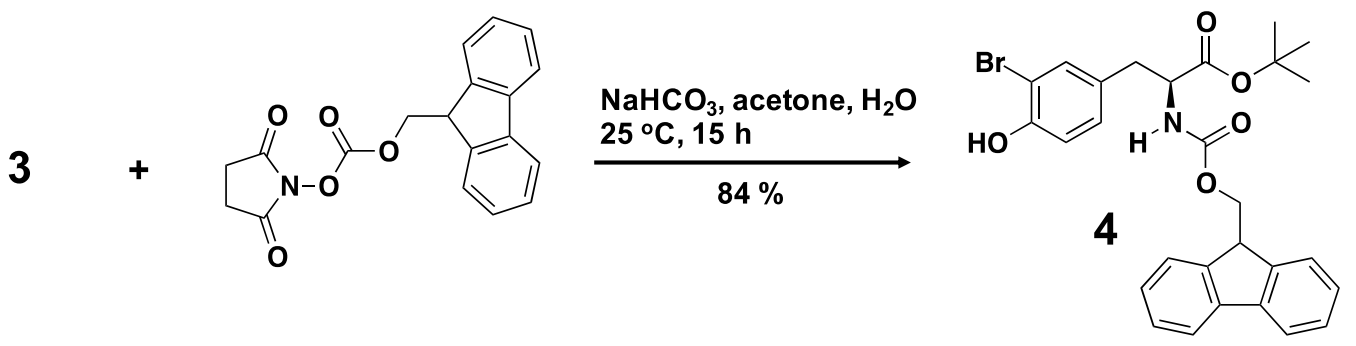

(S)-tert-Butyl 2-(\{[(9H-fluoren-9-yl)methoxy]carbonyl\}amino)-3-(3-bromo-4-hydroxyphenyl) propanoate (4). A suspension of $3(0.5 \mathrm{~g}, 1.6 \mathrm{mmol})$ and $\mathrm{NaHCO}_{3}(0.27 \mathrm{~g}, 3.2 \mathrm{mmol})$ in water $(20 \mathrm{~mL})$ was cooled to $0{ }^{\circ} \mathrm{C}$. Fmoc-Osu $(1.1 \mathrm{~g}, 3.2 \mathrm{mmol})$ in acetone $(40 \mathrm{~mL})$ was added to the suspension slowly, and the reaction mixture was then stirred at $25^{\circ} \mathrm{C}$ for $15 \mathrm{~h}$. The solvent was removed and washed with $1 \mathrm{NHCl}$ and water. After drying under vacuum, the crude product was purified by column chromatography on silica gel (eluent: ethyl acetate/hexane $=1: 3 \mathrm{v} / \mathrm{v})$ to yield compound $4(0.71 \mathrm{~g}, 84 \%) .{ }^{1} \mathrm{H}-\mathrm{NMR}(400 \mathrm{MHz}$, $\left.\mathrm{CDCl}_{3}\right): \delta=1.42\left(\mathrm{~s}, 9 \mathrm{H},-\mathrm{OC}\left(\mathrm{CH}_{3}\right)_{3}\right), 3.00\left(\mathrm{~d}, 2 \mathrm{H}, \mathrm{J}=5.6 \mathrm{~Hz}, \mathrm{HOPh}(\mathrm{Br})-\mathrm{CH}_{2} \mathrm{CH}\left(\mathrm{NHCOOCH}{ }_{2} \mathrm{CH}-\right)-\right)$, $4.21\left(\mathrm{t}, 1 \mathrm{H}, \mathrm{J}=7.2 \mathrm{~Hz}, \mathrm{HOPh}(\mathrm{Br})-\mathrm{CH}_{2} \mathrm{CH}\left(\mathrm{NHCOOCH}_{2} \mathrm{CH}-\right)-\right), 4.33$ (dd, $1 \mathrm{H}, \mathrm{J}=10.4,7.2 \mathrm{~Hz}$, $\left.\mathrm{HOPh}(\mathrm{Br})-\mathrm{CH}_{2} \mathrm{CH}\left(\mathrm{NHCOOCH}{ }_{2} \mathrm{CH}-\right)-\right)$, 4.43-5.00 (m, 2H, $\mathrm{HOPh}(\mathrm{Br})-\mathrm{CH}_{2} \mathrm{CH}\left(\mathrm{NHCOOCH} \mathrm{CH}_{-}\right)-$), $5.29\left(\mathrm{~d}, \quad 1 \mathrm{H}, \quad \mathrm{J}=8.0 \mathrm{~Hz}, \quad \mathrm{HOPh}(\mathrm{Br})-\mathrm{CH}_{2} \mathrm{CH}\left(\mathrm{NHCOOCH}_{2} \mathrm{CH}-\right)-\right), 5.43 \quad(\mathrm{~s}, \quad 1 \mathrm{H}$, $\left.\mathrm{HOPh}(\mathrm{Br})-\mathrm{CH}_{2} \mathrm{CH}\left(\mathrm{NHCOOCH}_{2} \mathrm{CH}-\right)-\right), 6.91(\mathrm{~d}, 1 \mathrm{H}, \mathrm{J}=8.4 \mathrm{~Hz}$, aromatic ring $), 6.96(\mathrm{~d}, 1 \mathrm{H}$, $\mathrm{J}=9.2 \mathrm{~Hz}$, aromatic ring), 7.26-7.33 (m, 3H, aromatic ring), $7.40(\mathrm{dd}, 2 \mathrm{H}, \mathrm{J}=7.4,7.4 \mathrm{~Hz}$, aromatic ring), $7.57(\mathrm{dd}, 2 \mathrm{H}, \mathrm{J}=6.2,6.2 \mathrm{~Hz}$, aromatic ring), $7.76(\mathrm{~d}, 2 \mathrm{H}, \mathrm{J}=7.2 \mathrm{~Hz}$, aromatic ring); high resolution mass spectrometry (HRMS) calculated for $\mathrm{C}_{28} \mathrm{H}_{28} \mathrm{BrNO}_{5}\left([\mathrm{M}+\mathrm{H}]^{+}\right)$: 538.1224 , found: 538.1224. 


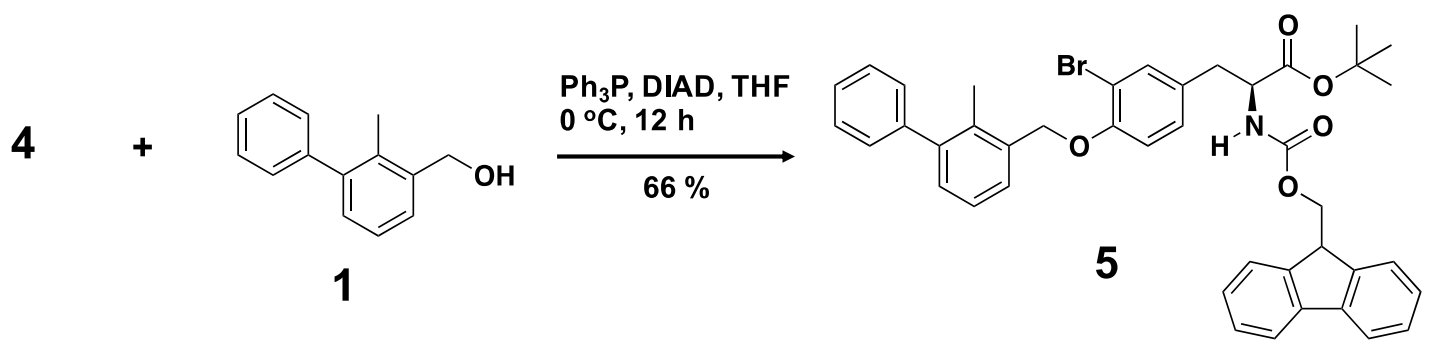

(S)-tert-Butyl 2-(\{[(9H-fluoren-9-yl)methoxy]carbonyl\}amino)-3-\{3-bromo-4-[(2-methyl-1,1' -biphenyl-3-yl)methoxy]phenyl propanoate (5). To a solution of 4 (0.1 g, $0.19 \mathrm{mmol})$, 3-hydroxymethyl-2-methylbiphenyl (1; $39 \mathrm{mg}, 0.20 \mathrm{mmol})$, and triphenyl phosphine $(57 \mathrm{mg}$, $0.20 \mathrm{mmol})$ in anhydrous THF $(10 \mathrm{~mL})$, DIAD $(0.1 \mathrm{~mL}, 0.22 \mathrm{mmol})$ was added at $0{ }^{\circ} \mathrm{C}$ under argon, and the reaction mixture was stirred at $0{ }^{\circ} \mathrm{C}$ for $12 \mathrm{~h}$ under argon. The organic phase was extracted with $\mathrm{CH}_{2} \mathrm{Cl}_{2}$ and dried over anhydrous magnesium sulfate. The solvent was then evaporated under reduced pressure, with the temperature kept below $30^{\circ} \mathrm{C}$. The crude product was purified by column chromatography on silica gel (eluent: ethyl acetate/hexane $=1: 4 \mathrm{v} / \mathrm{v})$ to yield compound $5(0.09 \mathrm{~g}, 66 \%)$. ${ }^{1} \mathrm{H}-\mathrm{NMR}\left(400 \mathrm{MHz}, \mathrm{CDCl}_{3}\right): \delta=1.46$ $\left(\mathrm{s}, 9 \mathrm{H},-\mathrm{OC}\left(\mathrm{CH}_{3}\right)_{3}\right), 2.27\left(\mathrm{~s}, 3 \mathrm{H}, \quad\right.$ Biphenyl $\left.\left(\mathrm{CH}_{3}\right)-\mathrm{CH}_{2} \mathrm{OPh}(\mathrm{Br})-\mathrm{CH}_{2} \mathrm{CH}\left(\mathrm{NHCOOCH} \mathrm{CH}_{-}\right)-\right)$, $3.05\left(\mathrm{~d}, \quad 2 \mathrm{H}, \quad \mathrm{J}=5.6 \mathrm{~Hz}, \quad \operatorname{Biphenyl}\left(\mathrm{CH}_{3}\right)-\mathrm{CH}_{2} \mathrm{OPh}(\mathrm{Br})-\mathrm{CH}_{2} \mathrm{CH}\left(\mathrm{NHCOOCH} \mathrm{CH}_{-}-\right)-\right.$, $4.23\left(\mathrm{t}, 1 \mathrm{H}, \mathrm{J}=7.6 \mathrm{~Hz}\right.$, Biphenyl $\left.\left(\mathrm{CH}_{3}\right)-\mathrm{CH}_{2} \mathrm{OPh}(\mathrm{Br})-\mathrm{CH}_{2} \mathrm{CH}\left(\mathrm{NHCOOCH}_{2} \mathrm{CH}-\right)-\right), 4.34$ $\left(\mathrm{dd}, \quad 1 \mathrm{H}, \quad \mathrm{J}=6.8, \quad 6.8 \mathrm{~Hz}, \quad \operatorname{Biphenyl}\left(\mathrm{CH}_{3}\right)-\mathrm{CH}_{2} \mathrm{OPh}(\mathrm{Br})-\mathrm{CH}_{2} \mathrm{CH}\left(\mathrm{NHCOOCH} \mathrm{CH}_{-}-\right)-\right)$, 4.46-4.56 (m, 2H, Biphenyl $\left.\left(\mathrm{CH}_{3}\right)-\mathrm{CH}_{2} \mathrm{OPh}(\mathrm{Br})-\mathrm{CH}_{2} \mathrm{CH}\left(\mathrm{NHCOOCH}_{2} \mathrm{CH}-\right)-\right)$, 5.13 (s, $2 \mathrm{H}$, Biphenyl $\left.\left(\mathrm{CH}_{3}\right)-\mathrm{CH}_{2} \mathrm{OPh}(\mathrm{Br})-\mathrm{CH}_{2} \mathrm{CH}\left(\mathrm{NHCOOCH}_{2} \mathrm{CH}-\right)-\right), 5.37(\mathrm{~d}, 1 \mathrm{H}, \mathrm{J}=7.6 \mathrm{~Hz}$, Biphenyl $\left.\left(\mathrm{CH}_{3}\right)-\mathrm{CH}_{2} \mathrm{OPh}(\mathrm{Br})-\mathrm{CH}_{2} \mathrm{CH}\left(\mathrm{NHCOOCH}_{2} \mathrm{CH}-\right)-\right), 6.92(\mathrm{~d}, 1 \mathrm{H}, \mathrm{J}=8.0 \mathrm{~Hz}$, aromatic ring), $7.05(\mathrm{~d}, 1 \mathrm{H}, \mathrm{J}=7.2 \mathrm{~Hz}$, aromatic ring), 7.19-7.45 $(\mathrm{m}, 14 \mathrm{H}$, aromatic ring), $7.53(\mathrm{~d}, 1 \mathrm{H}, \mathrm{J}=6.8 \mathrm{~Hz}$, aromatic ring), $7.60(\mathrm{dd}, 2 \mathrm{H}, \mathrm{J}=6.4,6.4 \mathrm{~Hz}$, aromatic ring), $7.77(\mathrm{~d}, 2 \mathrm{H}, \mathrm{J}=7.2 \mathrm{~Hz}$, aromatic ring); HRMS calculated for $\mathrm{C}_{42} \mathrm{H}_{40} \mathrm{BrNO}_{5}\left([\mathrm{M}+\mathrm{H}]^{+}\right)$: 718.2163, found: 718.2164 .
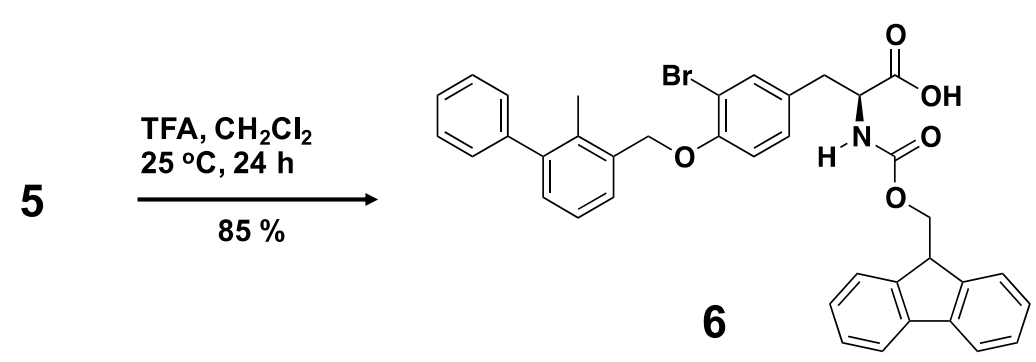

(S)-2-(\{[(9H-fluoren-9-yl)methoxy]carbonyl\}amino)-3-\{3-bromo-4-[(2-methyl-1,1'-biphenyl-3yl)methoxy]phenyl \}propanoic acid (6). A solution of 5 (3.9 g, $5.42 \mathrm{mmol})$ in anhydrous $\mathrm{CH}_{2} \mathrm{Cl}_{2}$ $(36 \mathrm{~mL})$ was stirred at $0{ }^{\circ} \mathrm{C}$ under argon for $15 \mathrm{~min}$. TFA $(1.3 \mathrm{~mL}, 16.6 \mathrm{mmol})$ was added dropwise to the solution at $0{ }^{\circ} \mathrm{C}$, and the reaction mixture was stirred at $25{ }^{\circ} \mathrm{C}$ under argon. After $6 \mathrm{~h}$, TFA $(1.5 \mathrm{~mL}, 19.5 \mathrm{mmol})$ was added to the reaction mixture, which was then stirred at $25{ }^{\circ} \mathrm{C}$ for $18 \mathrm{~h}$ under argon. The solvent was removed under reduced pressure, with the temperature kept below $40{ }^{\circ} \mathrm{C}$. The crude product was purified by column chromatography on silica gel (eluent: $\mathrm{CH}_{2} \mathrm{Cl}_{2} /$ methanol $\left.=97: 3 \mathrm{v} / \mathrm{v}\right)$ to yield compound $6(3.2 \mathrm{~g}, 85 \%)$. ${ }^{1} \mathrm{H}-\mathrm{NMR}$ $\left(400 \mathrm{MHz}, \mathrm{CDCl}_{3}\right): \delta=2.24\left(\mathrm{~s}, 3 \mathrm{H}\right.$, Biphenyl $\left.\left(\mathrm{CH}_{3}\right)-\mathrm{CH}_{2} \mathrm{OPh}(\mathrm{Br})-\mathrm{CH}_{2} \mathrm{CH}\left(\mathrm{NHCOOCH} \mathrm{CH}_{-}\right)-\right)$, $3.05\left(\mathrm{dd}, 1 \mathrm{H}, \mathrm{J}=14.0,6.0 \mathrm{~Hz}\right.$, Biphenyl $\left.\left(\mathrm{CH}_{3}\right)-\mathrm{CH}_{2} \mathrm{OPh}(\mathrm{Br})-\mathrm{CH}_{2} \mathrm{CH}\left(\mathrm{NHCOOCH} \mathrm{CH}_{-}\right)-\right)$, $3.15\left(\mathrm{dd}, 1 \mathrm{H}, \mathrm{J}=14.8,5.2 \mathrm{~Hz}\right.$, Biphenyl $\left(\mathrm{CH}_{3}\right)-\mathrm{CH}_{2} \mathrm{OPh}(\mathrm{Br})-\mathrm{CH}_{2} \mathrm{CH}\left(\mathrm{NHCOOCH} \mathrm{CH}_{-}-\right)-$, $4.21\left(\mathrm{t}, 1 \mathrm{H}, \mathrm{J}=6.8 \mathrm{~Hz}\right.$, Biphenyl $\left.\left(\mathrm{CH}_{3}\right)-\mathrm{CH}_{2} \mathrm{OPh}(\mathrm{Br})-\mathrm{CH}_{2} \mathrm{CH}\left(\mathrm{NHCOOCH}_{2} \mathrm{CH}-\right)-\right), \quad 4.36$ $\left(\mathrm{dd}, 1 \mathrm{H}, \mathrm{J}=6.8,6.8 \mathrm{~Hz}\right.$, Biphenyl $\left.\left(\mathrm{CH}_{3}\right)-\mathrm{CH}_{2} \mathrm{OPh}(\mathrm{Br})-\mathrm{CH}_{2} \mathrm{CH}\left(\mathrm{NHCOOCH} \mathrm{CH}_{2}\right)-\right), \quad 4.46$ $\left(\mathrm{dd}, 1 \mathrm{H}, \mathrm{J}=10.0,7.2 \mathrm{~Hz}\right.$, Biphenyl $\left.\left(\mathrm{CH}_{3}\right)-\mathrm{CH}_{2} \mathrm{OPh}(\mathrm{Br})-\mathrm{CH}_{2} \mathrm{CH}\left(\mathrm{NHCOOCH} \mathrm{CH}_{2}\right)-\right), \quad 4.66$ 
$\left(\mathrm{dd}, 1 \mathrm{H}, \mathrm{J}=13.2,6.0 \mathrm{~Hz}\right.$, Biphenyl $\left.\left(\mathrm{CH}_{3}\right)-\mathrm{CH}_{2} \mathrm{OPh}(\mathrm{Br})-\mathrm{CH}_{2} \mathrm{CH}\left(\mathrm{NHCOOCH} \mathrm{CH}_{-}\right)-\right), \quad 5.09$ (s, 2H, Biphenyl $\left.\left(\mathrm{CH}_{3}\right)-\mathrm{CH}_{2} \mathrm{OPh}(\mathrm{Br})-\mathrm{CH}_{2} \mathrm{CH}\left(\mathrm{NHCOOCH}_{2} \mathrm{CH}-\right)-\right), 5.23(\mathrm{~d}, 1 \mathrm{H}, \mathrm{J}=8.4 \mathrm{~Hz}$, Biphenyl $\left.\left(\mathrm{CH}_{3}\right)-\mathrm{CH}_{2} \mathrm{OPh}(\mathrm{Br})-\mathrm{CH}_{2} \mathrm{CH}\left(\mathrm{NHCOOCH}_{2} \mathrm{CH}-\right)-\right), 6.91(\mathrm{~d}, 1 \mathrm{H}, \mathrm{J}=8.8 \mathrm{~Hz}$, aromatic ring $), 7.03$ $(\mathrm{d}, 1 \mathrm{H}, \mathrm{J}=7.6 \mathrm{~Hz}$, aromatic ring), 7.21-7.55 $(\mathrm{m}, 15 \mathrm{H}$, aromatic ring), $7.74(\mathrm{~d}, 2 \mathrm{H}, \mathrm{J}=7.2 \mathrm{~Hz}$, aromatic ring); $\mathrm{HRMS}$ calculated for $\mathrm{C}_{38} \mathrm{H}_{32} \mathrm{BrNO}_{5}\left([\mathrm{M}+\mathrm{H}]^{+}\right)$: 662.1537, found: 662.1520 .

\subsection{Solid-State Peptide Synthesis}

Amino-Xs were synthesized using an automated peptide synthesizer (MultiPep CF, INTAVIS Bioanalytical Instruments AG, Cologne, Germany). The synthetic protocol for glycine-conjugated peptide XG was as follows: Fmoc-protected glycine attached to a polystyrene resin (Fmoc-Gly NovaSyn TGT, Merck KGaA, Darmstadt, Germany) was deprotected by piperidine $(20 \%$ in $\mathrm{N}$-methylpyrrolidone (NMP). The resulting resin was reacted with 6 (99 $\mathrm{mg}, 0.14 \mathrm{mmol}$ ), 1-[bis(dimethylamino)methylene]-1H-benzotriazolium 3-oxide hexafluorophosphate (HBTU; $150 \mu \mathrm{L}$, $0.5 \mathrm{M}$ in $N, N$-dimethylformamide (DMF), $N$-methylmorpholine $(45 \mu \mathrm{L}, 4.0 \mathrm{M}$ in DMF) in NMP $(8 \mu \mathrm{L})$ for $45 \mathrm{~min}$. After washing, the $\mathrm{N}$ - $\alpha$-protecting group of Fmoc in compound 6 was deprotected by piperidine ( $20 \%$ in NMP). Finally, the obtained peptide was cleaved from the resin using TFA (95\% in water), yielding XG. Other peptides were synthesized using a similar method. (S)-2-amino-3-[3-bromo-4-\{(2-methyl-1,1'-biphenyl-3-yl)methoxy\}phenyl]propanoic acid (X) was obtained by deprotection of Fmoc in 6 using piperidine (20\% in NMP).

\subsection{Characterization}

The synthesized compounds were identified using ${ }^{1} \mathrm{H}$ NMR spectroscopy (JNM-ECZ400R, JEOL Ltd., Tokyo, Japan) and HRMS (QSTAR Elite, AB SCIEX, Framingham, MA, USA).

\subsection{Determination of the $I C_{50}$ Value by AlphaLISA ${ }^{\circledR}$}

\subsubsection{Principle of the Competitive Binding Assay}

The binding affinity of the inhibitors to PD-L1 were measured using the AlphaLISA ${ }^{\circledR}$ assay kit (AL356 HV/C/F, PerkinElmer) according to the manufacturer's instructions, with the anti-PD-1 mAb nivolumab (Selleck Chemicals, Houston, TX, USA) included as a positive control [41]. In this assay, direct binding of an inhibitor to PD-L1 is detected by photoinduced energy transfer (Figure S6). Biotin-conjugated PD-1 is attached to streptavidin-coated donor beads and histidine (His)-tagged PD-L1 is attached to anti-His-conjugated acceptor beads. Photoexcitation of the donor beads at $680 \mathrm{~nm}$ yields singlet oxygen. If PD-L1-PD-1 binding is successful, energy is transferred through singlet oxygen, leading to an increase in fluorescence intensity at $615 \mathrm{~nm}$ (Figure S6).

\subsubsection{Preparation of Samples}

BMS-8 was purchased from AA Blocks LLC (San Diego, CA, USA). Stock solutions of inhibitors in DMSO (stock solution A, $5 \mathrm{mM}$ ) were serially diluted (Figure S5A) to obtain 10 assay solutions (1-10) with concentrations ranging from $5.0 \mathrm{mM}$ to $2.6 \mathrm{nM}$ (Table S2). An aliquot of solution 1-10 (2 $\mu \mathrm{L}$ ) was mixed with His-tagged PD-L1 $(25 \mathrm{nM}, 2 \mu \mathrm{L})$, biotin-conjugated PD-1 $(25 \mathrm{nM}, 2 \mu \mathrm{L})$, anti-His acceptor beads $\left(0.55 \mathrm{~g} \mathrm{~L}^{-1}, 2 \mu \mathrm{L}\right)$, and streptavidin-coated donor beads $\left(1.1 \mathrm{~g} \mathrm{~L}^{-1}, 2 \mu \mathrm{L}\right)$ (Figure S5B) in a final volume of $10 \mu \mathrm{L}$ and incubated at $25^{\circ} \mathrm{C}$ for $90 \mathrm{~min}$. Positive and negative technical controls were included in parallel. Positive controls contained buffer $(2 \mu \mathrm{L})$ in place of solution 1-10, and negative controls contained only the beads $(2 \mu \mathrm{L}$ each) and buffer $(6 \mu \mathrm{L})$.

\subsubsection{AlphaLISA ${ }^{\circledR}$ Measurement and Analysis}

The reaction samples $(10 \mu \mathrm{M})$ were placed in a 384-well microplate and photoirradiated at $680 \mathrm{~nm}$ from the top. Fluorescence at $615 \mathrm{~nm}$ was detected using an EnSpire multimode plate reader 
(Perkin Elmer, Waltham, MA, USA). $\mathrm{IC}_{50}$ values were estimated from a sigmoidal curve of fluorescence intensity vs. inhibitor concentration using a relative weighting method $\left(1 / \mathrm{Y}^{2}\right.$ weighting) with GraphPad Prism 8 (GraphPad Software Inc., San Diego, CA, USA).

\subsection{Docking Simulation of Compounds}

The docking simulation software ICM 3.8-7 [33] was used to investigate the binding modes of $\mathbf{X}$ and amino-Xs to the PD-L1 homodimer complexed with BMS-8 (PDB ID: 5J8O) [31]. We performed docking without template docking [37] or introducing flexibility [37] to avoid over-fitting of the ligands into the pocket. The docking simulation supposed Monte Carlo pseudo-Brownian motion [46]. In the simulation, the score suggests goodness of docking, defined as follows [45]:

$$
\text { Score }=\Delta E_{\text {IntFF }}+T \Delta S_{\text {Tor }}+\alpha_{1} \Delta E_{\text {HBond }}+\alpha_{2} \Delta E_{\text {HBDesol }}+\alpha_{3} \Delta E_{\text {solEl }}+\alpha_{4} \Delta E_{\text {HPob }}+\alpha_{5} Q_{\text {size }}
$$

where $\alpha_{1}-\alpha_{5}$ = weight, $\Delta E_{\text {IntFF }}=$ ligand-target van der Waals interactions and internal force field energy of the ligand, $T \Delta S_{\text {Tor }}=$ free energy changes due to conformational energy loss upon ligand binding, $\Delta E_{\mathrm{HBond}}=$ hydrogen bonding interactions, $\Delta E_{\mathrm{HBDesol}}=$ hydrogen bond donor-acceptor desolvation energy, $\Delta E_{\mathrm{solEl}}=$ solvation electrostatic energy upon ligand binding, $\Delta E_{\mathrm{HPob}}=$ hydrophobic free energy gain, and $Q_{\text {size }}=$ a size correction term proportional to the number of ligand atoms $[45,47,48]$. We calculated RMSD values by using CORREL function in the Microsoft Excel.

\section{Conclusions}

This study reports that we prepared the new biphenyl-conjugated bromotyrosine, which inhibits the PD-1/PD-L1 interaction with better effect than that of BMS-8. In addition, the amino-Xs, which are conjugates of $\mathbf{X}$ with a variety of amino acids, provide the molecular mechanism how amino acid modifications of $\mathbf{X}$ affects inhibition of PD-1/PD-L1 interactions. Binding of the $\mathbf{X}$ without the $\mathrm{C} \alpha, \mathrm{NH}_{2}$, and $\mathrm{COOH}$ atoms portion of amino-Xs into the PD-L1 binding pocket is required to promote transient homodimerization of $\mathrm{PD}-\mathrm{L} 1_{\mathrm{A}} / \mathrm{PD}-\mathrm{L} 1_{\mathrm{B}}$, leading to formation of a stable ternary complex composed of $\mathbf{X}$ and $\mathrm{PD}-\mathrm{L} 1_{\mathrm{AB}}$. Amino acid conjugation, however, alters the $\mathbf{X}$ docking conformation in the PD-L1 pocket, reducing the $\mathrm{IC}_{50}$ values dramatically. We conclude that improper interactions between amino acids conjugated to $\mathbf{X}$ and those in the binding pocket induced displacement of the compounds, thereby reducing inhibitory effect. In the future, we plan to design conjugates with amino acids that do not disturb the conformation of $\mathbf{X}$ in the PD-L1 binding pocket.

Supplementary Materials: The following are available online at http://www.mdpi.com/1422-0067/21/10/3639/s1.

Author Contributions: H.M., M.K., Y.I., and E.K. conceived the project. E.-H.K. and M.K. conducted the organic syntheses. H.M. and E.-H.K. performed the in silico simulations. E.-H.K., R.D., and H.M. measured the $\mathrm{IC}_{50}$ values by the AlphaLISA ${ }^{\circledR}$. E.-H.K., M.K., and H.M. wrote the manuscript. All of the authors discussed the results and approved the content of the final manuscript. All authors have read and agreed to the published version of the manuscript.

Funding: This study was partly supported by the Incentive Research Fund of RIKEN (FY2017-2018, H.M. and M.K.) and the Japan Agency for Medical Research and Development (AMED: FY2018-2020, Y.I.). E.-H.K. was financially supported by the Junior Research Associate Program at RIKEN.

Acknowledgments: We thank the Bio-material Analysis Support Unit, RIKEN Center for Brain Science for synthesis of biphenyl-conjugated amino acids. We thank Anne M. O’Rourke, from Edanz Group (www.edanzediting.com/ac) for editing a draft of this manuscript.

Conflicts of Interest: The authors declare no conflicts of interest. 


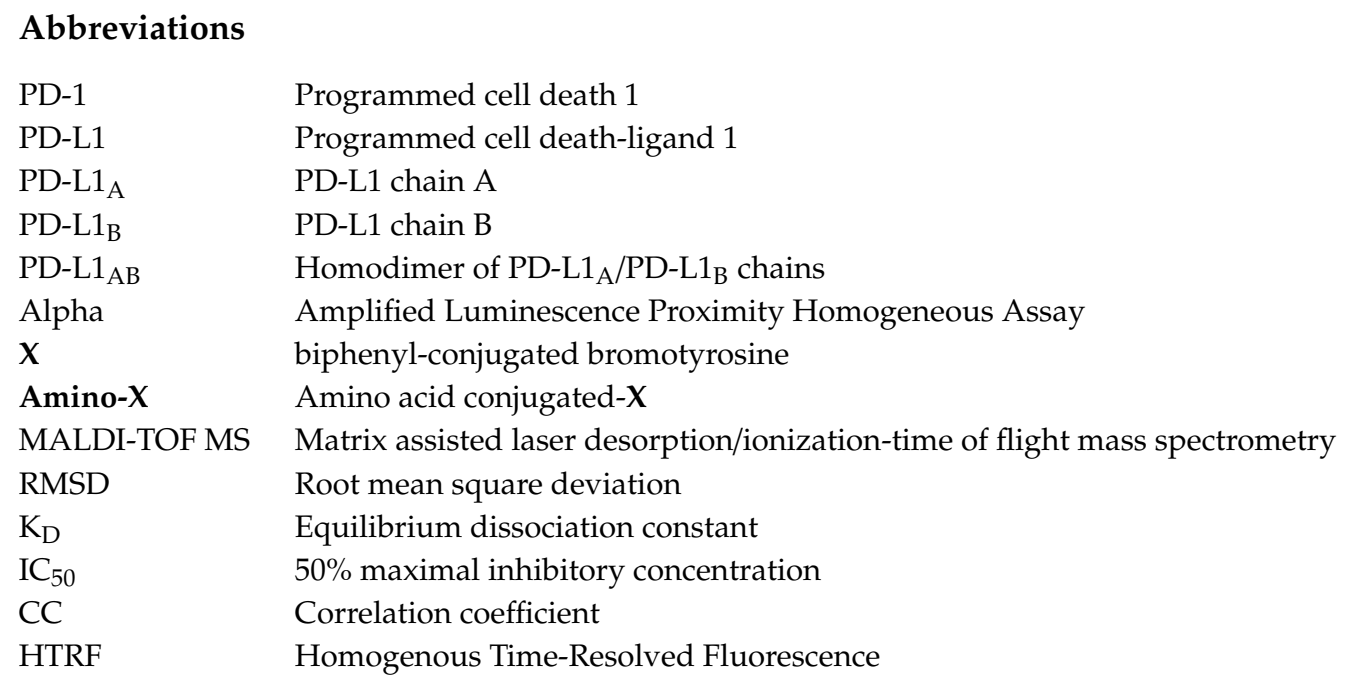

\section{References}

1. Rius, M.; Lyko, F. Epigenetic cancer therapy: Rationales, targets and drugs. Oncogene 2011, 31, 4257-4265. [CrossRef] [PubMed]

2. Postow, M.A.; Callahan, M.K.; Wolchok, J.D. Immune checkpoint blockade in cancer therapy. J. Clin. Oncol. 2015, 33, 1974-1982. [CrossRef]

3. Lee, L.; Gupta, M.; Sahasranaman, S. Immune Checkpoint inhibitors: An introduction to the next-generation cancer immunotherapy. J. Clin. Pharmacol. 2016, 56, 157-169. [CrossRef] [PubMed]

4. Hoos, A. Development of immuno-oncology drugs-from CTLA4 to PD1 to the next generations. Nat. Rev. Drug Discov. 2016, 15, 235-247. [CrossRef] [PubMed]

5. Iwai, Y.; Ishida, M.; Tanaka, Y.; Okazaki, T.; Honjo, T.; Minato, N. Involvement of PD-L1 on tumor cells in the escape from host immune system and tumor immunotherapy by PD-L1 blockade. Proc. Natl. Acad. Sci. USA 2002, 99, 12293-12297. [CrossRef] [PubMed]

6. Mellman, I.; Coukos, G.; Dranoff, G. Cancer immunotherapy comes of age. Nature 2011, 480, 480-489. [CrossRef]

7. Ishida, Y.; Agata, Y.; Shibahara, K.; Honjo, T. Induced expression of PD-1, a novel member of the immunoglobulin gene superfamily, upon programmed cell death. EMBO J. 1992, 11, 3887-3895. [CrossRef]

8. Dong, H.; Zhu, G.; Tamada, K.; Chen, L. B7-H1, a third member of the B7 family, co-stimulates T-cell proliferation and interleukin-10 secretion. Nat. Med. 1999, 5, 1365-1369. [CrossRef]

9. Freeman, G.J.; Long, A.J.; Iwai, Y.; Bourque, K.; Chernova, T.; Nishimura, H.; Fitz, L.J.; Malenkovich, N.; Okazaki, T.; Byrne, M.C.; et al. Engagement of the PD-1 immunoinhibitory receptor by a novel B7 family member leads to negative regulation of lymphocyte activation. J. Exp. Med. 2000, 192, 1027-1034. [CrossRef]

10. Dong, H.D.; Strome, S.E.; Salomao, D.R.; Tamura, H.; Hirano, F.; Flies, D.B.; Roche, P.C.; Lu, J.; Zhu, G.F.; Tamada, K.; et al. Tumor-associated B7-H1 promotes T-cell apoptosis: A potential mechanism of immune evasion. Nat. Med. 2002, 8, 793-800. [CrossRef]

11. Lee, K.M.; Chuang, E.; Griffin, M.; Khattri, R.; Hong, D.K.; Zhang, W.; Straus, D.; Samelson, L.E.; Thompson, C.B.; Bluestone, J.A. Molecular basis of T cell inactivation by CTLA-4. Science 1998, 282, 2263-2266. [CrossRef] [PubMed]

12. Stamper, C.C.; Zhang, Y.; Tobin, J.F.; Erbe, D.V.; Ikemizu, S.; Davis, S.J.; Stahl, M.L.; Seehra, J.; Somers, W.S.; Mosyak, L. Crystal structure of the B7-1/CTLA-4 complex that inhibits human immune responses. Nature 2001, 410, 608-611. [CrossRef] [PubMed]

13. Drake, C.G. Basic overview of current immunotherapy approaches in urologic malignancy. Urol. Oncol. Semin. Orig. Investig. 2006, 24, 413-418. [CrossRef]

14. Weiner, L.M.; Surana, R.; Wang, S. Monoclonal antibodies: Versatile platforms for cancer immunotherapy. Nat. Rev. Immunol. 2010, 10, 317-327. [CrossRef] [PubMed]

15. Guo, Y.-T.; Hou, Q.-Y.; Wang, N. Monoclonal antibodies in cancer therapy. Clin. Oncol. Cancer Res. 2011, 8, 215-219. [CrossRef] 
16. Pento, J.T. Monoclonal Antibodies for the Treatment of Cancer. Anticancer Res. 2017, 37, 5935-5939. [CrossRef]

17. Reichert, J.M. Monoclonal Antibodies as Innovative Therapeutics. Curr. Pharm. Biotechnol. 2008, 9, 423-430. [CrossRef]

18. Leach, D.R.; Krummel, M.F.; Allison, J.P. Enhancement of antitumor immunity by CTLA-4 blockade. Science 1996, 271, 1734-1736. [CrossRef]

19. Hodi, F.S.; O’Day, S.J.; McDermott, D.F.; Weber, R.W.; Sosman, J.A.; Haanen, J.B.; Gonzalez, R.; Robert, C.; Schadendorf, D.; Hassel, J.C.; et al. Improved survival with ipilimumab in patients with metastatic melanoma. New Engl. J. Med. 2010, 363, 711-723. [CrossRef]

20. Wang, C.Y.; Thudium, K.B.; Han, M.H.; Wang, X.T.; Huang, H.C.; Feingersh, D.; Garcia, C.; Wu, Y.; Kuhne, M.; Srinivasan, M.; et al. In vitro characterization of the anti-PD-1 antibody nivolumab, BMS-936558, and in vivo toxicology in non-human primates. Cancer Immunol. Res. 2014, 2, 846-856. [CrossRef]

21. Kimiz-Gebologlu, I.; Gulce-Iz, S.; Biray-Avci, C. Monoclonal antibodies in cancer immunotherapy. Mol. Boil. Rep. 2018, 45, 2935-2940. [CrossRef] [PubMed]

22. Suzuki, S.; Ishida, T.; Yoshikawa, K.; Ueda, R. Current status of immunotherapy. Jpn. J. Clin. Oncol. 2016, 46, 191-203. [CrossRef] [PubMed]

23. Zhang, H.; Chen, J. Current status and future directions of cancer immunotherapy. J. Cancer 2018, 9, $1773-1781$. [CrossRef] [PubMed]

24. Sharma, P.; Hu-Lieskovan, S.; Wargo, J.A.; Ribas, A. Primary, adaptive, and acquired resistance to cancer immunotherapy. Cell 2017, 168, 707-723. [CrossRef] [PubMed]

25. El-Osta, H.; Shahid, K.; Mills, G.M.; Peddi, P. Immune checkpoint inhibitors: The new frontier in non-small-cell lung cancer treatment. Onco Targets Ther. 2016, 9, 5101-5116. [CrossRef]

26. Shukla, A.A.; Thommes, J. Recent advances in large-scale production of monoclonal antibodies and related proteins. Trends Biotechnol. 2010, 28, 253-261. [CrossRef]

27. Chames, P.; Van Regenmortel, M.; Weiss, E.; Baty, D. Therapeutic antibodies: Successes, limitations and hopes for the future. Br. J. Pharmacol. 2009, 157, 220-233. [CrossRef]

28. Bojadzic, D.; Buchwald, P. Toward small-molecule inhibition of protein-protein interactions: general aspects and recent progress in targeting costimulatory and coinhibitory (immune checkpoint) interactions. Curr. Top. Med. Chem. 2018, 18, 674-699. [CrossRef]

29. Golani, L.K.; Wallace-Povirk, A.; Deis, S.M.; Wong, J.; Ke, J.; Gu, X.; Raghavan, S.; Wilson, M.R.; Li, X.; Polin, L.; et al. Tumor targeting with novel 6-substituted pyrrolo [2,3-d] pyrimidine antifolates with heteroatom bridge substitutions via cellular uptake by folate receptor alpha and the proton-coupled folate transporter and inhibition of de novo purine nucleotide biosynthesis. J. Med. Chem. 2016, 59, 7856-7876. [CrossRef]

30. Chupak, L.S.; Zheng, X. Compounds Useful as Immunomodulators. Bristol-Myers Squibb Company. WO2015034820 A1, 12 March 2015.

31. Zak, K.M.; Grudnik, P.; Guzik, K.; Zieba, B.J.; Musielak, B.; Dömling, A.S.S.; Dubin, G.; Holak, T.A. Holak. Structural basis for small molecule targeting of the programmed death ligand 1 (PD-L1). Oncotarget 2016, 7, 30323-30335. [CrossRef]

32. Musielak, B.; Kocik, J.; Skalniak, L.; Magiera-Mularz, K.; Sala, D.; Czub, M.; Stec, M.; Siedlar, M.; Holak, T.A.; Plewka, J. CA-170-A potent small-molecule PD-L1 inhibitor or not? Molecules 2019, 24, 2804. [CrossRef] [PubMed]

33. Abagyan, R.; Totrov, M.; Kuznetsov, D. ICM-A New method for protein modeling and design-applications to docking and structure prediction from the distorted native conformation. J. Comput. Chem. 1994, 15, 488-506. [CrossRef]

34. Bottegoni, G.; Kufareva, I.; Totrov, M.; Abagyan, R. Four-dimensional docking: A fast and accurate account of discrete receptor flexibility in ligand docking. J. Med. Chem. 2009, 52, 397-406. [CrossRef] [PubMed]

35. Bottegoni, G.; Kufareva, I.; Totrov, M.; Abagyan, R. A new method for ligand docking to flexible receptors by dual alanine scanning and refinement (SCARE). J. Comput. Aided. Mol. Des. 2008, 22, 311-325. [CrossRef]

36. Wang, W.; Hirano, Y.; Uzawa, T.; Liu, M.; Taiji, M.; Ito, Y. In vitro selection of a peptide aptamer that potentiates inhibition of cyclin-dependent kinase 2 by purvalanol. MedChemComm 2014, 5, 1400-1403. [CrossRef]

37. Dharmatti, R.; Miyatake, H.; Nandakumar, A.; Ueda, M.; Kobayashi, K.; Kiga, D.; Yamamura, M.; Ito, Y. Enhancement of binding affinity of folate to its receptor by peptide conjugation. Int. J. Mol. Sci. 2019, 20, 2152. [CrossRef] [PubMed] 
38. Eglen, R.M.; Reisine, T.; Roby, P.; Rouleau, N.; Illy, C.; Bosse, R.; Bielefeld, M. The use of AlphaScreen technology in HTS: Current status. Curr. Chem. Genom. 2008, 1, 2-10. [CrossRef]

39. Tan, S.; Zhang, H.; Chai, Y.; Song, H.; Tong, Z.; Wang, Q.; Qi, J.; Wong, G.; Zhu, X.; Liu, W.J.; et al. An unexpected N-terminal loop in PD-1 dominates binding by nivolumab. Nat. Commun. 2017, 8, 14369. [CrossRef]

40. Guzik, K.; Zak, K.M.; Grudnik, P.; Magiera, K.; Musielak, B.; Torner, R.; Skalniak, L.; Domling, A.; Dubin, G.; Holak, T.A. Small-molecule inhibitors of the programmed cell death-1/programmed death-ligand 1 (PD-1/PD-L1) interaction via transiently induced protein states and dimerization of PD-L1. J. Med. Chem. 2017, 60, 5857-5867. [CrossRef]

41. Skalniak, L.; Zak, K.M.; Guzik, K.; Magiera, K.; Musielak, B.; Pachota, M.; Szelazek, B.; Kocik, J.; Grudnik, P.; Tomala, M.; et al. Small-molecule inhibitors of PD-1/PD-L1 immune checkpoint alleviate the PD-L1-induced exhaustion of T-cells. Oncotarget 2017, 8, 72167-72181. [CrossRef]

42. Magiera-Mularz, K.; Skalniak, L.; Zak, K.M.; Musielak, B.; Rudzinska-Szostak, E.; Berlicki, L.; Kocik, J.; Grudnik, P.; Sala, D.; Zarganes-Tzitzikas, T.; et al. Bioactive macrocyclic inhibitors of the PD-1/PD-L1 immune checkpoint. Angew. Chem. Int. Ed. 2017, 56, 13732-13735. [CrossRef] [PubMed]

43. Lazar-Molnar, E.; Scandiuzzi, L.; Basu, I.; Quinn, T.; Sylvestre, E.; Palmieri, E.; Ramagopal, U.A.; Nathenson, S.G.; Guha, C.; Almo, S.C. Structure-guided development of a high-affinity human Programmed Cell Death-1: Implications for tumor immunotherapy. EBioMedicine 2017, 17, 30-44. [CrossRef]

44. Wang, W.; Hirano, Y.; Uzawa, T.; Taiji, M.; Ito, Y. Peptide-assisted enhancement of inhibitory effects of small molecular inhibitors for kinases. Bull. Chem. Soc. Jpn. 2016, 89, 444-446. [CrossRef]

45. Neves, M.A.; Totrov, M.; Abagyan, R. Docking and scoring with ICM: The benchmarking results and strategies for improvement. J. Comput. Mol. Des. 2012, 26, 675-686. [CrossRef] [PubMed]

46. Abagyan, R.; Totrov, M. Biased probability monte-carlo conformational searches and electrostatic calculations for peptides and proteins. J. Mol. Biol. 1994, 235, 983-1002. [CrossRef] [PubMed]

47. Totrov, M.; Abagyan, R. Flexible protein-ligand docking by global energy optimization in internal coordinates. Proteins 1997, 29 (Suppl. 1), 215-220. [CrossRef]

48. Schapira, M.; Totrov, M.; Abagyan, R. Prediction of the binding energy for small molecules, peptides and proteins. J. Mol. Recognit. 1999, 12, 177-190. [CrossRef]

(C) 2020 by the authors. Licensee MDPI, Basel, Switzerland. This article is an open access article distributed under the terms and conditions of the Creative Commons Attribution (CC BY) license (http://creativecommons.org/licenses/by/4.0/). 